\title{
Analysis of Council of Europe Convention on Offences relating to Cultural Property
}

\author{
Jing Changhao \\ Wuhan University of Technology, Wuhan Hubei \\ 373546952@qq.com \\ Jing Changhao
}

Keywords: Cultural property crime,Council of Europe,Convention,Protection.

\begin{abstract}
Council of Europe Convention on Offences relating to Cultural Property aims to prevent and combat the illicit traffic in and destruction of cultural property in the framework of the Organization's action against terrorism and organized crime. The Convention will be open for signature by any country in the world. Its purpose is also to promote international cooperation in combating these crimes that are destroying the world cultural heritage. For this convention, it is necessary to conduct a brief analysis of it to clarify its relevant content, including the emergence of the Convention and its main contents.
\end{abstract}

\section{Introduction}

Cultural property is a unique and important proof of the history and identity of different ethnic groups and is a common asset that should be preserved under any circumstances. These cultural properties are unique resources that are fragile and irreplaceable and should have the highest standards of management so that they can be enjoyed by both modern and future generations.

Unfortunately, the frequency of cultural property attacks in peace and warfare is very high, often resulting in the permanent loss of structures and objects important to the cultural heritage, thus making the entire human race poor. Cultural artifacts have been stolen and robbed from museums, galleries, public and private collections and religious buildings in other places, while important archeological sites and monuments have been illegally mined and destroyed.

Before the drafting of the convention, the number of looting and theft of antiquities in Western markets increased significantly, especially the collapse of law and order in these countries from Iraq and Syria's important sites. In response to these changing law enforcement challenges, international organizations and national entities must be able to take the necessary actions to prevent and stop such illegal cultural property transactions.

\section{The emergence of the Convention}

The Council of Europe Convention on Crimes in Cultural Property (known as the "Delphi Convention") was opened for signature by the member states of the Council of Europe on June 23, 1985 but never entered into force because only six countries signed it and No country approved. In order to ensure proper follow-up to the decisions of the Council of Ministers regarding the review of the Council of Europe Convention, to assess the possible added value of updating certain conventions, according to its responsibilities, the European Commission on Crimes (CDPC) decided that the European Commission should establish a criminal law convention, To combat trafficking in cultural property and fill gaps in the existing international legal framework.

On March 2, 2016, the Council of Europe Council of Ministers approved the terms of reference of the Powers Committee of the CDPC and Crime Committee on Cultural Property to draft a draft convention to replace the Delphi Convention. After the text was completed, the draft convention was transferred to the European Commission on Criminal Crimes for approval at the European special session from March 29 to March 31, 2017. Subsequently, the text of the Convention was 
sent to the meetings of the Council of Ministers and the Special Rapporteur on education, culture, sports, youth and the environment, which was then sent to the Council of Ministers and finally adopted at the ministerial meeting in Nicosia, Cyprus, on 19 May. Convention.

Based on more than 50 years of experience in promoting and improving cooperation in criminal matters between member states of the Council of Europe, the Convention is a criminal law convention designed to prevent and combat the deliberate destruction, damage and trafficking of cultural property while strengthening Criminal justice measures to promote cooperation at the international level. Throughout the work process, the drafters took into account the European Council's human rights and rule of law standards and best practices of member States and other international organizations and initiatives. The Convention aims to ensure that the Convention is highly compatible with the relevant existing international and supranational legal restraint standards based on documents concerning cultural property. Finally, it should be emphasized that the Convention was drafted not only in consideration of the members of the European Commission, but also to be an open, global-oriented convention to protect humanity's common cultural heritage.

\section{Content}

The Convention contains a total of eight chapters, including the purpose, scope and use of terms, substantive criminal law, Investigation, prosecution and procedural law, protective measures and other administrative measures, follow-up mechanisms, relations with other international instruments, amendments to the Convention, and final clauses. The following chapters will mainly analyze the chapter two chapters on substantive criminal law, chapter three Investigation, prosecution and procedural law, chapter four protection measures and administrative measures.

\subsection{Substantive Criminal Law}

Like the other European Council conventions that seek to combat specific forms of transnational crime, chapter II contains the substantive criminal law provisions of the Convention. The European Commission on Crimes conducted a comprehensive review of the national legislation on crimes involving cultural property and determined that there were some loopholes and problems. Therefore, it is necessary to draft substantive criminal law provisions to strengthen local, national and international efforts to protect cultural property. The drafters are committed to adopting common standards and legislative measures to deal with the most common and serious crimes that may cause the destruction, deterioration or loss of cultural property, including actions against transnational organized crime and terrorism. These measures will not hinder the obligation of all countries to protect the rights recognized by the "Convention on the Protection of Human Rights and Fundamental Freedoms". Therefore, the second chapter represents the core content of the Convention and should be read in accordance with the preamble and the objectives and purposes of the Convention set forth in Articles 1 and 2.

Articles 3 to 9 are designed to ensure that different parts of the phenomenon known as trafficking in cultural property are criminalized. Therefore, these terms have been drafted to complement each other. Taking into account the dynamics of trafficking in cultural property stolen or illegally tapped during times of peace or during armed conflicts, the situation becomes clear. After dismantling, these items are usually shipped abroad. The transnational nature of illegal activities is due to the fact that experienced thieves and smugglers are aware of the legal differences between countries and try to use legal gaps or weaknesses to increase their illegal activities and reduce their chances of arrest. Handicrafts stolen or illegally excavated are often diverted to countries that are easily concealed by customs and border officials. These contaminated titles can be washed (for example, by protecting the integrity of the purchaser's specifications or deadlines) and then sold to private or Institutional collectors, or mature art trading companies such as art dealers or private galleries.

Crimes that do not directly affect the integrity of cultural property are not covered in Chapter 2 . This is the case with making or selling forged artworks. The reason is that while such illegal activities may undermine the stability and security of the art market and commercial transactions, 
these activities do not have a direct impact on the preservation of cultural heritage. On the other hand, the use of cultural property for the purpose of cleaning up criminal proceeds and money laundering has not been included in the scope of these substantive criminal law provisions because there are other conventions that deal with these issues, such as the Council' s Europe' s anti-money laundering, search, seizure and confiscation of proceeds of crime. Convention on the Financing of Terrorism and the Convention of the European Commission on Money Laundering, Search, Seizure and Confiscation of Proceeds of Crime.

The crimes contained in chapter II are punished only if they are deliberately implemented. There is an additional requirement for the offences of import, acquisition and placing of the market described in Article 5, paragraph 1, Article 7, paragraph 1 and Article 8, paragraph 1, that criminals are aware of the illicit origin of culture. The interpretation of criminal intent is resolved by domestic law, but the requirement for intentional conduct involves all elements of crime. Like the European Commission's criminal law practice, this does not mean that parties are not allowed to go beyond this minimum requirement and also criminalize non-intentional behavior. The obligation to ensure that this act constitutes a "criminal offence" requires States to apply their respective domestic law provisions in the course of criminal proceedings and the implementation of criminal sanctions. The word "ensure" means that a party may have to take legislative or other measures to fulfill this obligation. However, Parties may not need to take any such action as long as their national legislation fully complies with the obligations set out in this chapter. The Convention sets a minimum standard under which domestic legislation must ensure that at least the acts described in this chapter constitute a criminal offence. However, Parties may be outside the scope of the definition of crimes in this chapter and may also criminalize other forms of criminal activity. Ensuring that this act constitutes a "criminal crime" obligation does not rule out the possibility that member states may follow their legislative practice, and also foreses that administrative proceedings allow for administrative or other non-criminal sanctions in cases that are considered to be less serious and therefore do not apply criminal sanctions.

\subsection{Investigation, Prosecution and Procedural Law}

According to the provisions of Article 17 of the Convention, it aims to enable public authorities to prosecute criminal offences referred to in this Convention in accordance with their functions, without the victims having to file complaints.The main purpose of Article 18 is to invite States to take measures to train or contact experts in charge of criminal proceedings related to cultural property. In addition, article 19 lays down the general principle that international cooperation in criminal matters should be administered: Paragraph 1 provides that each party is obliged, under the relevant international and national law, to cooperate in the investigation or prosecution of the crimes referred to in this Convention to the greatest extent possible. Including measures for seizure and confiscation. Paragraph 2 invites a Party to assist each other in criminal matters or extradition on the condition that there is a treaty, and the legal basis for considering the Convention as judicial cooperation with a party that does not mention treaty relations is in paragraph 1 . This provision is a concern because of the possibility of signing a convention with third countries. The requested party will take action in accordance with the relevant provisions of its domestic law, which may stipulate the conditions or reasons for rejection. The additional reference to articles 16 and 18 of the Convention here is to indicate that the parties are also likely to apply these provisions in this regard, even if the UNTOC Convention cannot be applied because a particular type of crime exceeds its scope. s application. Any action taken pursuant to this paragraph shall be in full compliance with the obligations of the parties under international law, including obligations under international human rights instruments.

\subsection{Protection Measures and Administrative Measures}

The recent Criminal Law Convention of the European Commission stipulates provisions aimed at preventing criminal activities. This Convention is no exception. Drafters believe that these 
preventive measures should be implemented at the domestic and international levels before they can enter into force. The State party should consider adopting legislation and other necessary measures to achieve the purposes of the Convention. In essence, it is recommended that States parties deal with these measures for preventive purposes in order to reduce the possibility of the crimes listed in this Convention, since the use of criminal sanctions is a last resort based on the principle of final ratios. The State party should cooperate to the maximum extent possible with a view to preventing and combating the deliberate destruction, destruction and trafficking of cultural property.

\section{References}

[1] Council of Europe Convention on Offences relating to Cultural Property, https://www.coe.int/en/web/conventions/full-list/-/conventions/rms/0900001680710435,March 26, 2018.

[2] https:/www.coe.int/en/web/conventions/full-list/-/conventions/treaty/221/signatures?p_auth=pc vIDTHD,March 26, 2018. 